\title{
Hubungan Usia, Stres, dan Asupan Zat Gizi Makro dengan Kejadian Obesitas Abdominal pada Ibu Rumah Tangga di Kelurahan Sidotopo, Surabaya
}

\author{
The Association between Age, Stress Level, Macronutrient Intake and \\ Abdominal Obesity among Housewives in Sidotopo, Surabaya
}

\author{
Fitria Nurrahmawati*, Widati Fatmaningrum ${ }^{1}$
}

\begin{abstract}
ABSTRAK
Latar Belakang: Obesitas abdominal merupakan salah satu faktor risiko terjadinya penyakit kardiovaskuler. Obesitas terjadi akibat adanya ketidakseimbangan energi masuk dan keluar dari tubuh. Perempuan berisiko lebih tinggi mengalami obesitas abdominal dibandingkan laki-laki.

Tujuan: Tujuan penelitian ini adalah untuk menganalisis hubungan usia, stres, dan asupan zat gizi makro dengan kejadian obesitas abdominal pada ibu rumah tangga di Kelurahan Sidotopo, Surabaya. Metode: Penelitian cross sectional ini dilakukan di Kelurahan Sidotopo, Kecamatan Semampir, Kota Surabaya pada bulan Mei-Juli 2018. Sebesar 46 orang ibu rumah tangga usia 20-49 tahun dipilih secara acak menggunakan metode multistage random sampling. Hubungan antara usia, stres, dan asupan zat gizi makro dengan kejadian obesitas abdominal dianalisis menggunakan uji korelasi Pearson dan regresi logistik dengan tingkat signifikansi $<0,05$.

Hasil: Sebesar $52,17 \%$ responden mengalami obesitas abdominal. Sebagian besar responden berusia 30-39 tahun dimana berasal dari etnis Jawa dan Madura. Hasil penelitian menunjukkan bahwa obesitas abdominal berhubungan signifikan dengan usia $(p=0,001)$ dan stres $(p=0,017)$. Sebaliknya, asupan energi $(p=0,234)$, karbohidrat $(p=0,300)$, protein $(p=0,147)$, lemak $(p=0,188)$, dan asupan serat $(p=0,062)$ tidak menunjukkan hubungan yang signifikan dengan kejadian obesitas abdominal.

Kesimpulan: Usia dan tingkat stres berhubungan dengan kejadian obesitas abdominal pada ibu rumah tangga di Kelurahan Sidotopo. Semakin tinggi usia dan tingkat stres, maka resiko terjadinya obesitas abdominal akan semakin tinggi.
\end{abstract}

Kata Kunci: obesitas abdominal, stres, asupan zat gizi makro

\section{ABSTRACT}

Background: Abdominal obesity is one of the risk factors of cardiovascular diseases. Obesity is caused by energy imbalance. Women have higher risk of abdominal obesity than men.

Objectives: This study aimed to analyze the association between age, stress level, macronutrient intake with abdominal obesity among housewives in Sidotopo, Surabaya.

Method: This cross sectional study was conducted between May and July of 2018 in Kelurahan Sidotopo, Kecamatan Semampir, Kota Surabaya. The sample was 46 housewives aged between 20 and 49 years which was selected using multistage random sampling method. The association between age, stress level, and macronutrient intake with abdominal obesity was analysed using Pearson correlation and logistic regression test with a significant level of 0.05 .

Results: This study showed that $52.17 \%$ of housewives had abdominal obesity. Most of housewives were Javanese and Maduranes between the ages of 30-39. This study showed the significant association between age $(p=0.001)$ and stress level $(p=0.017)$ with abdominal obesity. Meanwhile, 
energy intake ( $p=0.062)$, carbohydrate intake $(p=0.300)$, protein intake $(p=0.147)$, fat intake $(p=0.188)$, and dietary fiber intake $(p=0.062)$ did not show significant association.

Conclusion: Age and stress level associated with abdominal obesity among housewives in Sidotopo. The risk of abdominal obesity increased with age and stress level.

Keywords: Abdominal obesity, Stres level, Macronutrient intake

*Koresponden:

fitrianurrahmawati1995@gmail.com

${ }^{1}$ Fakultas Kedokteran, Universitas Airlangga, Surabaya

Jawa Timur, Indonesia

\section{PENDAHULUAN}

Obesitas adalah kondisi dimana terjadi kelebihan lemak tubuh. ${ }^{1}$ Prevalensi obesitas di dunia cenderung terus meningkat. Pada tahun 2014, prevalensi overweight pada dewasa berusia lebih dari 18 tahun mencapai 39\% dimana $15 \%$ diantaranya merupakan perempuan. ${ }^{2}$ Prevalensi tersebut meningkat 2 kali lebih besar dibandingkan prevalensi obesitas pada tahun $1980 .^{2}$ Di Kota Surabaya, persentase obesitas meningkat dari $48,32 \%$ pada tahun 2014 menjadi $82,81 \%$ pada tahun 2015. ${ }^{3}$

Obesitas terjadi akibat adanya ketidakseimbangan energi dimana asupan yang dikonsumsi lebih besar dibandingkan aktivitas fisik yang dilakukan. Obesitas dapat ditentukan melalui pengukuran antropometri, seperti indeks massa tubuh (IMT), distribusi lemak tubuh atau persen lemak tubuh berdasarkan tebal lemak bawah kulit, dan lingkar perut. ${ }^{4}$ Rasio lingkar perut dan lingkar pinggul digunakan untuk membedakan obesitas abdominal dimana persebaran lemak di abdomen dan visceral atau obesitas perifer dimana persebaran lemak di pantat dan kaki. ${ }^{5}$ Lemak yang menumpuk di jaringan visceral atau abdominal merupakan pemicu terjadinya obesitas abdominal. ${ }^{5}$

Obesitas abdominal merupakan faktor risiko terjadinya penyakit kardiovaskular. Obesitas erat kaitannya dengan kejadian sindrom metabolik. Sebagian besar individu yang mengalami sindrom metabolik mengalami obesitas abdominal tanpa faktor risiko lain. ${ }^{6}$ Lingkar perut merupakan salah satu indikator yang dapat digunakan untuk mengukur massa lemak abdomen. ${ }^{7}$ Penelitian terdahulu menunjukkan bahwa lingkar perut merupakan indikator penting terhadap terjadinya perubahan metabolik dan kelainan kardiovaskuler. ${ }^{8,9}$

Beberapa penelitian menemukan bahwa obesitas abdominal lebih sering terjadi pada wanita. ${ }^{10,11} \mathrm{Hal}$ ini dikarenakan cadangan lemak tubuh pada wanita lebih tinggi dibandingkan pada laki-laki. ${ }^{12}$ Selain itu, perempuan cenderung memiliki aktivitas fisik lebih rendah dibandingkan laki-laki, terutama ibu rumah tangga. ${ }^{11}$ Kurangnya aktivitas fisik dan konsumsi karbohidrat berlebih merupakan faktor risiko utama terjadinya obesitas pada wanita yang tinggal di kawasan pemukimanan padat. ${ }^{13}$ Kegiatan rumah tangga yang dilakukan setiap hari menjadikan ibu rumah tangga tidak sempat melakukan aktivitas fisik. ${ }^{14}$

Pemilihan makan yang tidak tepat dapat meningkatkan resiko terjadinya obesitas abdominal. Pemilihan makanan yang kurang sehat, seperti konsumsi karbohidrat dan lemak berlebihan memiliki resiko lebih besar mengalami obesitas abdominal. ${ }^{8}$ Wanita yang tinggal di kawasan pemukiman padat cenderung memiliki status ekonomi rendah yang berdampak pada pemilihan makan. Obesitas yang terjadi pada wanita dengan sosio ekonomi rendah berhubungan dengan pemilihan makanan yang kurang tepat dimana cenderung mengonsumsi makanan tinggi kalori, tinggi karbohidrat, tinggi lemak, dan rendah protein. $^{15}$ Konsumsi tinggi protein dapat menurunkan jumlah lemak abdominal sehingga dapat menurunkan resiko terjadinya obesitas abdominal ${ }^{16}$. Selain itu, konsumsi makanan tinggi serat, seperti sayur dan buah 
dapat menurunkan resiko terjadinya obesitas abdominal. ${ }^{17}$ Penelitian terdahulu menemukan bahwa konsumsi buah $>3$ kali/minggu dapat menurunkan resiko terjadinya obesitas abdominal.

Semakin meningkat usia, maka resiko terjadinya obesitas abdominal semakin meningkat. Penelitian sebelumnya menunjukkan bahwa obesitas abdominal meningkat pada kelompok usia 30 tahun ke atas. ${ }^{18}$ Risiko obesitas abdominal meningkat 1,02 kali lebih besar pada individu dengan kelompok usia lebih tinggi. ${ }^{19}$

Stres merupakan salah satu factor resiko terjadinya obesitas abdominal. penelitian sebelumnya menunjukkan bahwa kejadian obesitas abdominal meningkat pada individu yang mengalami stress. ${ }^{10,20} \mathrm{lbu}$ rumah tangga memiliki rutinitas rumah tangga yang tinggi dan berulang setiap harinya, seperti mencuci baju, memasak, merawat anak, dan membersihkan rumah. ${ }^{21}$ Penelitian terdahulu menemukan bahwa ibu rumah tangga yang menggunakan jasa asisten rumah tangga (ART) cenderung memiliki tingkat stres lebih rendah. ${ }^{22} \mathrm{Hal}$ ini menunjukkan bahwa rutinitas rumah tangga dapat meningkatkan terjadinya stres.

Berdasarkan uraian tersebut, maka rumusan masalah pada penelitian ini adalah "Bagaimana hubungan usia, stres, asupan zat gizi makro dengan kejadian obesitas abdominal pada ibu rumah tangga di Kelurahan Sidotopo?". Tujuan penelitian ini adalah untuk menganalisis hubungan usia, stres, asupan zat gizi makro dengan kejadian obesitas abdominal pada ibu rumah tangga di Kelurahan Sidotopo.

\section{METODE}

Penelitian cross sectional ini dilakukan di Kelurahan Sidotopo, Kecamatan Semampir, Kota Surabaya pada bulan Mei - Juli 2018. Lokasi tersebut dipilih karena daerah Sidotopo merupakan salah satu Kawasan Pemukiman Padat di Kota Surabaya dengan tingkat kepadatan penduduk yang tinggi ${ }^{23}$. Sebesar 46 ibu rumah tangga yang telah memenuhi kriteria inklusi dan eksklusi dipilih secara acak dengan menggunakan metode multistage random sampling. Kriteria inklusi penelitian ini adalah ibu rumah tangga dengan usia 20-49 tahun, belum mengalami menopause, dan bermukim di Kelurahan Sidotopo selama $\geq 3$ bulan. Sedangkan kriteria eksklusi dari penelitian ini adalah perempuan hamil, menderita penyakit yang menyebabkan kenaikan berat badan, seperti oedema akibat gagal ginjal kronik, sakit parah sehingga tidak dapat dilakukan penelitian, dan memiliki disabilitas (cacat fisik).

Karakteristik individu dan sosial ekonomi responden dikumpulkan melalui metode wawancara menggunakan kuisioner terstruktur. Kategori stres dinilai menggunakan kuesioner Self Reporting Questionnaire (SRQ) yang dikembangkan oleh World Health Organization $^{24}$. Kuesioner ini terdiri dari 20 buah pertanyaan. Untuk setiap respon "ya" pada tiap pertanyaan, menghasilkan skor 1 dan setiap respon "tidak" menghasilkan skor 0 . Skor dijumlah dari keseluruhan pertanyaan dan dikategorikan menjadi stres apabila memiliki skor minimal 6 dari skor maksimal 20.

Asupan zat gizi diperoleh melalui wawancara konsumsi makanan menggunakan metode food recall $3 \times 24$ jam. Data makanan yang dikonsumsi diolah menggunakan software NutriSurvey for Windows tahun 2007, untuk menghasilkan data asupan rata-rata energi dan zat gizi dalam sehari, yang kemudian disajikan dalam bentuk data kontinyu dan kategori. Asupan energi, karbohidrat, lemak, dan protein dikategorikan menjadi 3 berdasarkan Widyakarya Nasional Pangan dan Gizi (WNPG) tahun 2004, yaitu kurang apabila asupan $<80 \%$ AKG, baik apabila asupan 80 $110 \%$ AKG, dan lebih apabila asupan $>110 \%$ AKG. ${ }^{25}$ Sedangkan asupan serat dikategorikan menjadi 2, yaitu kurang apabila asupan $<77 \%$ AKG dan baik apabila $\geq 77 \%$ AKG. ${ }^{26}$

Lingkar perut diukur dengan menggunakan instrumen waist ruler atau medline merk OneMed produksi OneMed Building Krian, Indonesia, kapasitas $150 \mathrm{~cm}$ dengan ketelitian $0,1 \mathrm{~cm}$. Pengukuran lingkar perut dimulai dari titik tengah dan melingkari pinggang dan perut hingga kembali menuju titik tengah di awal pengukuran. ${ }^{27}$ Jika responden memiliki perut buncit, pengukuran 
dilakukan melewati pusar responden. Pengukuran dilakukan sebanyak dua kali untuk setiap responden dan data yang digunakan adalah rata-rata hasil pengukuran. Responden dikategorikan mengalami obesitas abdominal apabila lingkar perut $\geq 80 \mathrm{~cm}$ dan tidak mengalami obesitas abdominal apabila lingkar perut $<80 \mathrm{~cm} .{ }^{28}$

Analisis statistik dilakukan menggunakan software IBM SPSS Statistics for Windows versi 21 tahun 2012. Uji statistik yang digunakan dalam penelitian ini adalah uji korelasi Pearson dengan tingkat signifikansi $0,05(p<0,05)$ untuk mengetahui hubungan usia, stres, asupan zat gizi makro dengan kejadian obesitas abdominal pada ibu rumah tangga dan uji regresi logistik untuk mengetahui besar faktor risiko kejadian obesitas abdominal.

Penelitian ini telah mendapat izin dari Komisi Etik Fakultas Kesehatan Masyarakat Universitas Airlangga Surabaya dengan Nomor 196-KEPK tanggal 24 April 2018 serta Badan Kesatuan Bangsa dan Politik (Bangkesbangpol) Kota Surabaya dengan Nomor 070/3605/436.8.5/2008 tanggal 30 April 2018.

\section{HASIL DAN PEMBAHASAN}

Distribusi karakteristik responden berdasarkan umur, etnis, pendidikan terakhir, dan tingkat pendapatan disajikan pada Tabel 1. Sebagian besar responden berusia 30-39 tahun dimana berasal dari etnis Jawa dan Madura. Etnis akan mempengaruhi pola makan individu dimana berkaitan dengan adanya tradisi dan budaya. ${ }^{29}$ Mayoritas responden merupakan ibu rumah tangga dengan pendidikan terakhir SMA dan memiliki pendapatan rumah tangga di bawah UMK Kota Surabaya, yaitu sebesar Rp3.300.000,00. ${ }^{30}$ Pendidikan berpengaruh terhadap tingkat pengetahuan individu sehingga akan meningkatkan kesadaran tentang perilaku hidup sehat. ${ }^{31}$ Kesadaran untuk berperilaku hidup sehat akan mendorong individu untuk melakukan pemilihan makan yang tepat dan aktivitas fisik. Tingkat pendapatan akan memengaruhi daya beli seseorang. Daya beli yang rendah akan berdampak pada pemilihan makanan yang kurang tepat. ${ }^{15}$ Sebagian besar responden pada penelitian ini tidak mengalami stres.
Sebagian besar ibu rumah tangga
berusia $30-39$ tahun mengalami obesitas abdominal. Sebaliknya, sebagian besar responden pada kelompok usia lebih rendah tidak mengalami obesitas abdominal (Tabel 1 ). Berdasarkan analisis dengan menggunakan uji korelasi Pearson pada Tabel 3, usia secara signifikan berhubungan cukup erat dengan kejadian obesitas abdominal ( $p=0,001$; $r=0,465)$. Resiko terjadinya obesitas abdominal meningkat 1,155 kali lebih besar seiring bertambahnya usia. Pada Gambar 1. dapat dilihat bahwa semakin tinggi usia, maka resiko meningkatnya lingkar perut akan semakin tinggi. Beberapa penelitian terdahulu menunjukkan hasil yang konsisten dimana terdapat hubungan yang signifikan antara usia dan kejadian obesitas abdominal dimana prevalensi obesitas abdominal lebih tinggi pada usia yang lebih tua. ${ }^{8,10,17,32}$ Seiring bertambahnya usia, proses metabolisme tubuh akan cenderung menurun yang akan menyebabkan fungsi otot menurun dan kadar lemak tubuh meningkat. ${ }^{33}$ Jika tidak diimbangi dengan gaya hidup sehat, seperti pengaturan pola makan dan aktivitas fisik, maka akan terjadi penumpukan lemak tubuh, terutama lemak di abdomen yang akan meningkatkan resiko terjadinya obesitas abdominal. ${ }^{8}$

Berdasarkan Tabel 1, di antara responden yang mengalami stres, sebesar $69,2 \%$ responden memiliki lingkar perut $>80$ $\mathrm{cm}$ atau mengalami obesitas abdominal. Sedangkan, di antara responden yang tidak mengalami stres, sebesar $45,5 \%$ mengalami obesitas abdominal. Penelitian ini menunjukkan bahwa terdapat hubungan yang positif antara stres dengan lingkar perut dimana nilai $p=0,017$ dan nilai $r=0,349$ (Gambar 2). Penelitian ini menunjukkan bahwa responden yang mengalami stres memiliki resiko mengalami obesitas abdominal 1,23 kali lebih besar dibanding dengan reponden tidak stres. Penelitian sebelumnya menemukan bahwa kejadian obesitas abdominal meningkat pada individu yang mengalami stres atau gangguan mental emosional yang terganggu. ${ }^{10,20}$ Ini berkaitan dengan adanya perubahan hormon ketika individu mengalami stres. 
Tabel 1. Distribusi Karakteristik Ibu Rumah Tangga di Kelurahan Sidotopo

\begin{tabular}{|c|c|c|c|c|}
\hline \multirow{3}{*}{ Karakteritik } & \multicolumn{4}{|c|}{ Status Obesitas Abdominal } \\
\hline & \multicolumn{2}{|c|}{ Obesitas Abdominal } & \multicolumn{2}{|c|}{ Non Obesitas Abdominal } \\
\hline & $\mathbf{N}$ & $\%$ & $\mathbf{n}$ & $\%$ \\
\hline \multicolumn{5}{|l|}{ Umur } \\
\hline $20-29$ tahun & 7 & 35 & 13 & 65 \\
\hline $30-39$ tahun & 13 & 61,9 & 8 & 38,1 \\
\hline $40-49$ tahun & 4 & 80 & 1 & 20 \\
\hline \multicolumn{5}{|l|}{ Etnis } \\
\hline Jawa & 12 & 50 & 12 & 50 \\
\hline Madura & 11 & 52,4 & 10 & 47,6 \\
\hline Lainnya & 1 & 100 & 0 & 0 \\
\hline \multicolumn{5}{|l|}{ Pendidikan Terakhir } \\
\hline Tidak tamat SD & 1 & 100 & 0 & 0 \\
\hline Tamat SD & 8 & 61,5 & 5 & 38,5 \\
\hline Tamat SMP & 5 & 45,5 & 6 & 54,5 \\
\hline Tamat SMA & 10 & 47,6 & 11 & 52,4 \\
\hline \multicolumn{5}{|l|}{ Tingkat Penghasilan } \\
\hline $\begin{array}{l}\text { Upah Minimum Kota (UMK) } \\
\text { Surabaya }^{30}(\geq \text { Rp3.300.000,00) }\end{array}$ & 4 & 57,1 & 3 & 42,9 \\
\hline $\begin{array}{l}\text { Di bawah UMK }(< \\
\text { Rp3.300.000,00) }\end{array}$ & 20 & 51,3 & 19 & 48,7 \\
\hline \multicolumn{5}{|l|}{ Stres } \\
\hline Stres & 9 & 69,2 & 4 & 30,8 \\
\hline Tidak Stres & 15 & 45,5 & 18 & 54,5 \\
\hline
\end{tabular}

Tabel 2. Distribusi Responden berdasarkan Asupan Makanan

\begin{tabular}{|c|c|c|c|c|}
\hline \multirow{3}{*}{ Asupan } & \multicolumn{4}{|c|}{ Status Obesitas Abdominal } \\
\hline & \multicolumn{2}{|c|}{ Obesitas Abdominal } & \multicolumn{2}{|c|}{ Non Obesitas Abdomina } \\
\hline & $n$ & $\%$ & $n$ & $\%$ \\
\hline \multicolumn{5}{|l|}{ Asupan Energi } \\
\hline Kurang (<80\% AKG) & 21 & 58,3 & 15 & 41,7 \\
\hline Baik (80 - 110\% AKG) & 3 & 30 & 7 & 70 \\
\hline Lebih (> 110\% AKG) & 0 & 0 & 0 & 0 \\
\hline \multicolumn{5}{|l|}{ Asupan Karbohidrat } \\
\hline Kurang (<80\% AKG) & 20 & 51,3 & 19 & 48,7 \\
\hline Baik (80 - 110\% AKG) & 4 & 57,1 & 3 & 42,9 \\
\hline Lebih (> 110\% AKG) & 0 & 0 & 0 & 0 \\
\hline \multicolumn{5}{|l|}{ Asupan Lemak } \\
\hline Kurang (<80\% AKG) & 14 & 58,3 & 10 & 41,7 \\
\hline Baik $(80-110 \%$ AKG) & 8 & 57,1 & 6 & 42,9 \\
\hline Lebih (> 110\% AKG) & 2 & 25 & 6 & 75 \\
\hline \multicolumn{5}{|l|}{ Asupan Protein } \\
\hline Kurang (<80\% AKG) & 10 & 58,8 & 7 & 41,2 \\
\hline Baik (80 - 110\% AKG) & 12 & 48 & 13 & 52 \\
\hline Lebih (> 110\% AKG) & 1 & 33,3 & 2 & 66,7 \\
\hline \multicolumn{5}{|l|}{ Asupan Serat } \\
\hline Kurang (<77\% AKG) & 24 & 52,2 & 22 & 47,8 \\
\hline Baik ( $\geq 77 \%$ AKG) & 0 & 0 & 0 & 0 \\
\hline
\end{tabular}


Tabel 3.Hubungan usia, stres, asupan zat gizi makro dengan kejadian obesitas abdominal pada ibu rumah tangga

\begin{tabular}{lcccc}
\hline \multicolumn{1}{c}{ Variabel } & OR & $\mathbf{9 5 \%}$ & p value & r value \\
\hline Usia (tahun) & 1,155 & $1,026-1,301$ & 0,001 & 0,465 \\
Stres & 1,230 & $1,032-1,466$ & 0,017 & 0,349 \\
Asupan Energi (kkal) & 0,999 & $0,997-1,001$ & 0,234 & $-0,179$ \\
Asupan Karbohidrat (gram) & 0,992 & $0,981-1,003$ & 0,300 & $-0,156$ \\
Asupan Protein (gram) & 0,925 & $0,854-1,001$ & 0,147 & $-0,220$ \\
Asupan Lemak (gram) & 0,968 & $0,924-1,013$ & 0,188 & $-0,198$ \\
Asupan Serat (gram) & 0,764 & $0,584-1,001$ & 0,062 & $-0,278$ \\
\hline
\end{tabular}

Tabel 4. Hubungan ketertarikan emosional saat menonton TV dengan Stres

\begin{tabular}{|c|c|c|c|c|c|c|c|c|}
\hline \multirow{3}{*}{$\begin{array}{l}\text { Ketertarikan emosional } \\
\text { saat menonton TV }\end{array}$} & \multicolumn{6}{|c|}{ Status Stres } & \multirow{3}{*}{ OR } & \multirow{3}{*}{$\begin{array}{c}\mathbf{p} \\
\text { value }\end{array}$} \\
\hline & \multicolumn{2}{|c|}{ Stress } & \multicolumn{2}{|c|}{ Tidak Stres } & \multicolumn{2}{|c|}{ Total } & & \\
\hline & $n$ & $\%$ & $n$ & $\%$ & $\mathbf{N}$ & $\%$ & & \\
\hline Ya & 11 & 44 & 14 & 56 & 25 & 100 & 7010 & 1000 \\
\hline Tidak & 2 & 9,5 & 19 & 90,5 & 21 & 100 & 1,464 & 0,010 \\
\hline
\end{tabular}

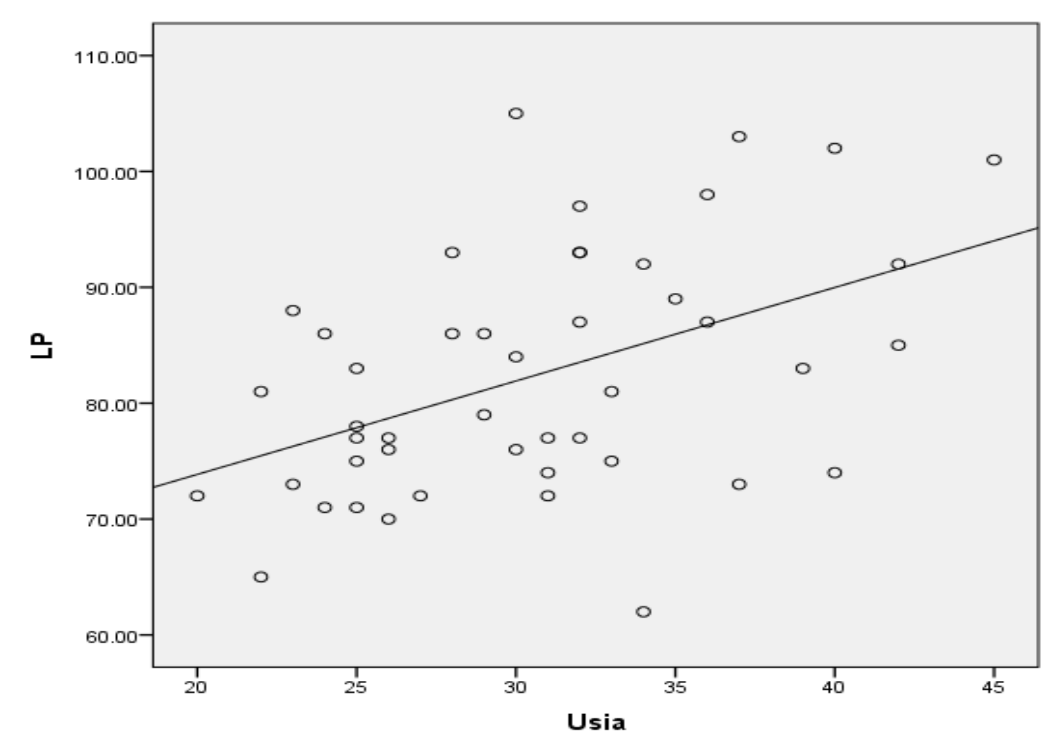

Gambar 1. Scatter plot Usia dengan Lingkar Perut Ibu Rumah Tangga di Kelurahan Sidotopo

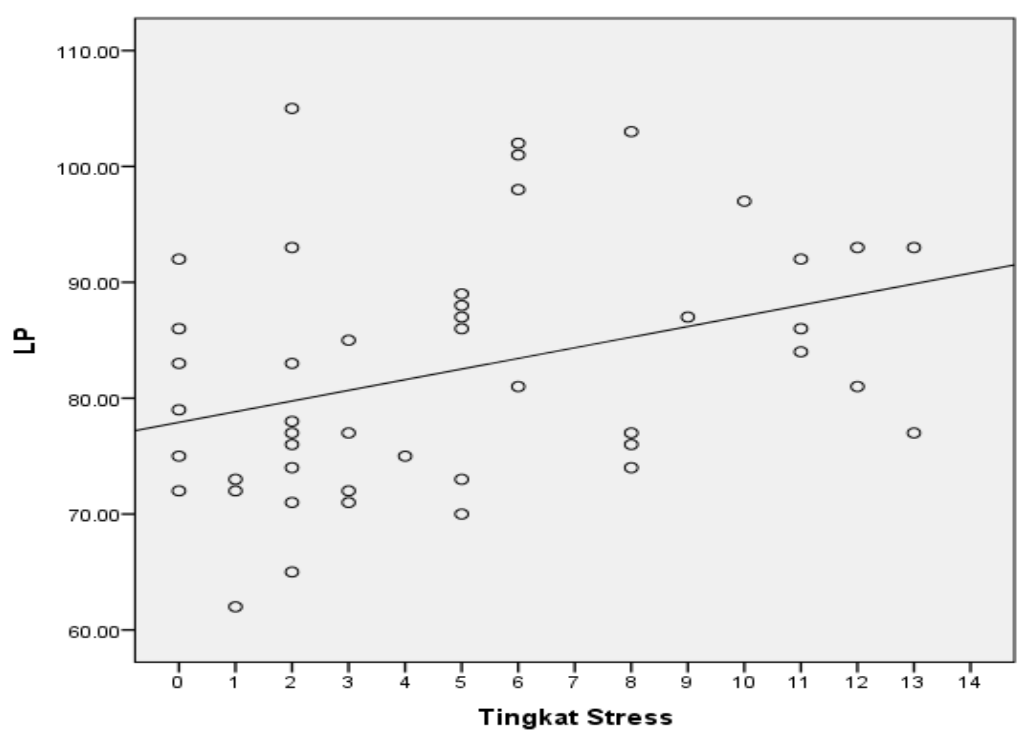

Gambar 2. Scatter plot Stres dengan Lingkar Perut Ibu Rumah Tangga di Kelurahan Sidotopo 
Saat stres, hipotalamus akan merangsang kelenjar pituitari untuk memproduksi hormon kortisol. Hormon kortisol yang tinggi akan menstimulasi terjadinya glikogenesis dan glukoneogenesis serta menyebabkan terjadinya resistensi insulin. ${ }^{34}$ Sekresi hormon kortisol dapat menstimulasi otak untuk meningkatkan nafsu makan. ${ }^{35}$ Peningkatan asupan makanan diimbangi dengan adanya hiperglikemia dapat menyebabkan obesitas. ${ }^{34}$

Sebagian besar ibu rumah tangga di Kelurahan Sidotopo memilih menonton TV sebagai salah satu bentuk coping stress yang dilakukan saat stres. Penelitian sebelumnya menjelaskan menonton TV dapat memengaruhi emosi individu dimana perubahan emosi terkait erat dengan kejadian stress. $^{36}$ Berdasarkan hasil wawancara, sebagian besar responden ikut merasa emosional saat menonton TV, terutama saat menonton serial drama dan sinetron. Penelitian ini menunjukkan bahwa stres pada ibu rumah tangga di Kelurahan Sidotopo berhubungan signifikan $(p=0,010)$ dengan ketertarikan emosional saat menonton TV (Tabel 4). Ibu rumah tangga yang tertarik emosional saat menonton TV berisiko mengalami stres 7,464 kali lebih besar dibandingkan ibu rumah tangga yang tidak tertarik emosional. Keadaan ini menunjukkan ketertarikan emosional saat menonton TV secara tidak langsung berhubungan dengan kejadian obesitas abdominal.

Sebagian besar responden yang mengalami obesitas abdominal maupun tidak obesitas abdominal mengonsumsi energi, karbohidrat, dan lemak kurang dari angka kecukupan gizi (AKG) yang dianjurkan (Tabel 2). Di antara responden dengan asupan energi kurang, sebesar 58,3\% ibu rumah tangga mengalami obesitas abdominal. Sebaliknya, sebesar $30 \%$ responden dengan asupan energi baik memiliki lingkar perut $\geq 80 \mathrm{~cm}$. Berdasarkan Tabel 3, asupan energi tidak berhubungan signifikan dengan kejadian obesitas abdominal pada ibu rumah tangga di Kelurahan Sidotopo $(p=0,234)$. Penelitian ini bertentangan dengan penelitian terdahulu yang menyatakan bahwa konsumsi energi berlebih dapat menyebabkan terjadinya obesitas sentral. ${ }^{8,35}$ Secara teori, konsumsi energi dalam jumlah tinggi dan tidak diimbangi dengan aktivitas fisik dapat menyebabkan obesitas. ${ }^{37}$ Penelitian ini serupa dengan penelitian terdahulu dimana tidak menunjukkan adanya hubungan signifikan antara asupan energi dan kejadian obesitas abdominal. ${ }^{11}$ Perbedaan hasil penelitian ini dapat disebabkan karena sebagian besar ibu rumah tangga yang mengalami obesitas abdominal mengonsumsi energi dalam jumlah kurang. Berdasarkan hasil Studi Diet Total tahun 2014, sebagian besar penduduk dewasa di Indonesia memiliki asupan energi kurang. ${ }^{38}$ Rendahnya asupan energi dapat disebabkan karena kurangnya asupan karbohidrat dimana karbohidrat merupakan penyumbang terbesar asupan energi masyarakat Indonesia. ${ }^{38}$

Pada penelitian ini, asupan karbohidrat tidak berhubungan signifikan $(p=0,300)$ dengan kejadian obesitas abdominal (Tabel 3). Perbedaan hasil ini dapat disebabkan karena diantara responden dengan asupan karbohidrat kurang dan baik, persentase responden dengan obesitas abdominal dan normal tidak jauh berbeda. Keadaan ini dapat berkaitan dengan kurangnya asupan energi responden. Penelitian terdahulu juga menemukan bahwa asupan karbohidrat tidak berhubungan signifikan dengan kejadian obesitas abdominal. ${ }^{11}$ Penelitian ini bertentangan dengan penelitian terdahulu dimana risiko obesitas meningkat 1,5 kali pada wanita dengan konsumsi karbohidrat berlebih. ${ }^{13}$ Karbohidrat disimpan dalam bentuk glikogen di dalam tubuh. Jika simpanan glikogen berlebih, maka karbohidrat dikonversi menjadi asam lemak dan disimpan dalam bentuk trigliserida. Penumpukan trigliserida dalam tubuh akan memicu terjadinya obesitas. ${ }^{39}$

Sebagian besar responden dengan asupan lemak kurang mengalami obesitas abdominal, sedangkan sebagian besar responden dengan asupan lemak tinggi tidak mengalami obesitas abdominal. Pada penelitian ini, asupan lemak tidak menunjukkan adanya hubungan signifikan dengan kejadian obesitas abdominal $(p=0,188)$. Penelitian ini serupa dengan 
penelitian terdahulu yang tidak menemukan hubungan signifikan antara konsumsi lemak dengan kejadian obesitas abdominal ${ }^{11}$. Tidak adanya perbedaan yang signifikan dapat disebabkan karena sebagian besar ibu rumah tangga dengan asupan energi kurang mengalami obesitas abdominal. Keadaan tersebut menyebabkan munculnya kesadaran ibu rumah tangga yang mengalami obesitas abdominal untuk mengurangi konsumsi makanan sumber lemak. Obesitas abdominal tidak terjadi dalam waktu singkat sehingga metode food recall hanya menggambarkan asupan makan saat ini, sedangkan obesitas disebabkan oleh kebiasaan makanan responden terdahulu. Penelitian terdahulu menemukan bahwa prevalensi obesitas meningkat pada individu dengan konsumsi lemak berlebih. ${ }^{8,15}$ Konsumsi lemak berlebih akan meningkatkan penyimpanan lemak pada jaringan adipose. ${ }^{40}$

Lebih dari 50\% responden mengonsumsi protein dengan jumlah yang baik (Tabel 2). Di antara asupan protein kurang, sebesar $58,8 \%$ responden mengalami obesitas abdominal. Berdasarkan uji korelasi Pearson, asupan protein tidak memiliki hubungan yang signifikan dengan lingkar perut pada ibu rumah tangga di Kelurahan Sidotopo $(p=0,147)$. Meskipun tidak signifikan, dapat diketahui bahwa terdapat kecenderungan bahwa semakin tinggi asupan protein, maka resiko peningkatan lingkar perut akan semakin rendah. Adanya perbedaan hasil dengan penelitian sebelumnya dapat disebabkan karena sebagian besar responden pada kedua kelompok dalam penelitian ini mengonsumsi protein dalam jumlah baik. Persebaran asupan protein responden pada kedua kelompok tidak berbeda jauh sehingga kurang dapat menggambarkan hubungan kemaknaannya. Penelitian ini tidak konsisten dengan penelitian sebelumnya yang menyatakan bahwa asupan tinggi protein akan meningkatkan resiko terjadinya kejadian obesitas abdominal. ${ }^{35}$ Namun, terdapat pula penelitian lain yang menunjukkan bahwa konsumsi protein dengan jumlah tinggi dapat menurunkan jumlah lemak abdominal ${ }^{16}$. Hal ini dikarenakan konsumsi protein dengan jumlah tinggi akan meningkatkan plasma leusin dimana akan menstimulasi sintesis protein di otot rangka dan meningkatkan oksidasi lemak. ${ }^{41}$ Selain itu, asupan tinggi protein dapat meningkatkan pengeluaran energi dan menambah efek termogenik. ${ }^{16}$

Konsumsi serat seluruh responden dalam penelitian ini di bawah angka kecukupan serat yang dianjurkan (Tabel 2). Berdasarkan Tabel 3, tidak terdapat hubungan yang signifikan antara asupan serat dengan kejadian obesitas abdominal $(p=0,062)$. Meskipun tidak terdapat hubungan yang signifikan, nilai $r$ menunjukkan kecenderungan semakin tinggi serat yang dikonsumsi, maka lingkar perut responden akan semakin rendah. Pada penelitian ini, konsumsi serat seluruh responden berada di bawah angka kecukupan gizi yang disarankan, yaitu 23 gram. Hal tersebut dapat menyebabkan adanya perbedaan hasil penelitian dengan penelitian sebelumnya. Penelitian sebelumnya menunjukkan diet tinggi serat berpengaruh terhadap lingkar perut responden. ${ }^{42}$ Konsumsi sayur dan buah dimana merupakan sumber serat dapat menurunkan resiko terjadinya obesitas. ${ }^{17} \mathrm{Hal}$ ini dikarenakan konsumsi serat akan memicu rasa kenyang, menurunkan absorpsi makronutrien, dan merubah sekresi hormon pencernaan..$^{43}$ Makanan tinggi serat membutuhkan waktu yang lebih lama untuk dicerna karena memiliki kemampuan untuk menahan air. ${ }^{42}$ Serat dapat memperlambat pengosongan lambung dengan memperlambat penyerapan lemak dan karbohidrat di usus halus sehingga akan menunda rasa $\operatorname{lapar}^{44}$. Hal ini dikarenakan serat mampu mengikat garam empedu sehingga semakin banyak serat yang dikonsumsi maka garam empedu dan lemak yang akan dikeluarkan dari tubuh melalui feses akan semakin tinggi. ${ }^{40}$

Keterbatasan dalam penelitian ini adalah peneliti hanya mengamati usia, tingkat stres, dan asupan zat gizi makro sebagai faktor risiko terjadinya obesitas abdominal pada ibu rumah tangga. Berdasarkan teori, obesitas terjadi karena adanya ketidakseimbangan energi masuk dan energi keluar. Peneliti tidak melakukan pengukuran aktivitas fisik pada penelitian ini sehingga diperlukan penelitian lainnya agar dapat menjelaskan kejadian obesitas abdominal pada ibu rumah tangga. 
Selain itu, pada penelitian ini, obesitas abdominal hanya diukur dengan menggunakan lingkar perut. Hal ini dikarenakan adanya keterbatasan alat dimana instrumen lain membutuhkan biaya yang lebih besar. Kelebihan penelitian ini adalah peneliti menghubungkan bentuk coping stress dengan kejadian stres dimana merupakan faktor resiko obesitas abdominal.

\section{KESIMPULAN}

Usia dan stres berhubungan dengan kejadian obesitas abdominal pada ibu rumah tangga di Kelurahan Sidotopo, Kecamatan Semampir, Kota Surabaya. Berdasarkan penelitian ini, semakin tinggi usia dan tingkat stres, maka resiko kejadian obesitas abdominal akan semakin tinggi. Ketertarikan emosional saat menonton TV meningkatkan resiko terjadinya stres yang merupakan faktor risiko terjadinya obesitas abdominal. Di lain pihak, asupan energi, karbohidrat, protein, lemak, dan serat tidak memiliki hubungan yang signifikan dengan kejadian obesitas abdominal.

\section{ACKNOWLEDGEMENT}

Peneliti mengucapkan terimakasih kepada seluruh responden, para kader di setiap RW yang terlibat di Kelurahan Sidotopo, dan Puskesmas Sidotopo. Selain itu, ucapan terimakasih juga diberikan kepada seluruh staff pengajar program Studi S1 Gizi Fakultas Kesehatan Masyarakat Universitas Airlangga.

\section{REFERENSI}

1. World Health Organization. Appropriate body-mass index for Asian populations and its implications for policy and intervention strategies. The Lancet 363 , 157-163 (2004).

2. World Health Organization. Global Status Report on Noncommunicable Diseases 2014. (2014).

3. Dinas Kesehatan Kota Surabaya. Profil Kesehatan Kota Surabaya Tahun 2015. (2015).

4. Widyastuti, N. \& Subagio, H. W. Hubungan Beberapa Indikator Obesitas dengan Hipertensi pada Perempuan. (2004).

5. Porth, C. M. Essentials of Pathophysiology. (Lisa McAllister, 2015).

6. Ramadhany, M. \& Nugroho, P. Hubungan Obesitas Terhadap Pengendalian Tekanan Darah Pasien Hipertensi Di Poliklinik Ilmu Penyakit Dalam RSUPN Cipto Mangunkusumo. (2013).

7. Mertens, I. L. \& Gaal, L. F. Van. Overweight, Obesity, and Blood Pressure : The Effects of Modest Weight Reduction. Obesity Research 8, 270-278 (2000).

8. Trisna, I. \& Hamid, S. Faktor-Faktor Yang Berhubungan Dengan Obesitas Sentral Pada Wanita Dewasa (30-50 Tahun) Di Kecamatan Lubuk Sikaping Tahun 2008. Jurnal Kesehatan Masyarakat 3, 68-71 (2009).

9. Natalia, D., Hasibuan, P. \& Hendro. Hubungan Obesitas dengan Kejadian Hipertensi di Kecamatan Sintang , Kalimantan Barat. CDK-228 42, 336-339 (2015).

10. Sugianti, E. Faktor Risiko Obesitas Sentral Pada Orang Dewasa Di Sulawesi Utara, Gorontalo Dan Dki Jakarta. (Institut Pertanian Bogor, 2009).

11. Fridawanti, A. P. Hubungan antara Asupan Energi, Karbohidrat, Protein, dan Lemak terhadap Obesitas Sentral pada Orang Dewasa di Desa Kepuharjo, Kecamatan Cangkringan, Yogyakarta. (Univeristas Sanata Dharma, 2016).

12. Pujiati, S. Prevalensi Dan Faktor Risiko Obesitas Sentral Pada Penduduk Dewasa Kota Dan Kabupaten Indonesia Tahun 2007. (Universitas Indonesia, 2010).

13. Purwaningrum, D. N., Hasanbasri, M. \& Trisnantoro, L. Obesity and the poor women living in urban slum areas: health system response. BMC Public Health 12, 2458 (2012).

14. Pratiwi, A. A. \& Nindya, T. S. Hubungan Konsumsi Camilan dan Durasi Waktu Tidur dengan Obesitas di Permukiman Padat Kelurahan Simolawang, Surabaya. Amerta Nutrition 1, 153 (2017).

15. Yulia, Khusun, H. \& Fahmida, U. Dietary 
patterns of obese and normal-weight women of reproductive age in urban slum areas in Central Jakarta. British Journal of Nutrition 116, S49-S56 (2016).

16. Arciero, P. J. et al. Increased Protein Intake and Meal Frequency Reduces Abdominal Fat During Energy Balance and Energy Deficit. Obesity 21, 13571366 (2013).

17. Sharma, S. K., Sangrulkar, T. V, Brahmankar, T. R. \& Vishwanath, G. R. Study of overweight and obesity and its risk factors among adults in an adopted urban slum area of Government Medical College, Miraj. International Journal of Community Medicine and Public Health 4, 1744-1750 (2017).

18. Chakraborty, R., Bose, K. \& Kozie, S. Waist circumference in determining obesity and hypertension among $18-60$ years old Bengalee Hindu male slum dwellers in Eastern India. Annals of Human Biology 1-7 (2011). doi:10.3109/03014460.2011.605396

19. Pradeepa, R. et al. prevalence of generalized \& abdominal obesity in urban \& rural - the ICMR-INDIAB Study (Phase-I) [ICMR-INDIAB-3] Rajendra. Indian J Med Res 142, 139-150 (2015).

20. Nyanseor, S. W. The Effects of Psychological Stress on Abdominal Obesity Among African American Women. (Georgia State University, 2016).

21. Yuhaniz, M. \& Jusan, M. M. The Role and Activities of Malay Housewives and their Influence on Housing Design Preferences. Procedia - Social and Behavioral Sciences 222, 720-728 (2016).

22. Putri, K. A. K. \& Sudhana, H. Perbedaan Tingkat Stres Pada Ibu Rumah Tangga yang Menggunakan dan Tidak Menggunakan Pembantu Rumah Tangga. Jurnal Psikologi Udayana 1, 94105 (2013).

23. Barbara, P. B. \& Umilia, E. Clustering Permukiman Kumuh di Kawasan Pusat Kota Surabaya. Jurnal Teknik POMITS 3, C-172-C-177 (2014).

24. Beusenberg, M. \& Orley, J. A user's guide to the Self Reporting Questionnaire (SRQ). World Health Organization (1994).

25. Loliana, N. \& Nadhiroh, S. R. Asupan dan kecukupan gizi antara remaja obesitas dengan non obesitas. Media Gizi Indonesia 10, 141-145 (2012).

26. Gibson, R. S. Principles of Nutritional Assessment. (Oxford University Press Inc., 2005).

27. Kementerian Kesehatan RI. Pedoman Pengisian Kuesioner. (2013).

28. World Health Organization. The AsiaPacific Perspective : Redefining Obesity. (2000).

29. Sulastri, D. \& Ramadhani, R. Hubungan obesitas dengan kejadian hipertensi pada masyarakat etnik minangkabau di kota padang. Majalah Kedokteran Andalas 36, 188-201 (2012).

30. Gubernur Jawa Timur. Peraturan Gubernur Jawa Timur Nomor 121 Tahun 2016 Tentang Upah Minimum Kabupaten/Kota Di Jawa Timur Tahun 2017. (2016).

31. Rahajeng, E. \& Tuminah, S. Prevalensi Hipertensi dan Determinannya di Indonesia. Majalah Kedokteran Indonesia 59, 580-587 (2009).

32. Haregu, T. N., Oti, S., Egondi, T. \& Kyobutungi, C. Measurement of overweight and obesity an urban slum setting in sub-Saharan Africa: a comparison of four anthropometric indices. BMC Obesity 3, 1-8 (2016).

33. Novitasary, M. D., Mayulu, N. \& Kawengian, S. E. . Hubungan antara Aktivitas Fisik dengan Obesitas pada Wanita Usia Subur Peserta Jamkesmas di Puskesmas Wawonasa Kecamatan Singkil Manado. Jurnal e-Biomedik (eBM) 1, 1040-1046 (2013).

34. Kruit, R. Obesity due to stress. (Utrecht University, 2013).

35. Rahmawati, D. Faktor-Faktor yang Berhubungan dengan Obesitas Sentral pada Mahasiswa Program Studi Kesehatan Masyarakat UIN Syarif Hidayatullah Jakarta Angkatan 20122014. (Universitas Islam Negeri Syarif Hidayatullah, 2015). 
36. Septianie, A. S. Pengaruh Menonton Tayangan Sinetron Love In Paris Terhadap Perubahan Perilaku Remaja Pada Siswa Smp Negeri 4 Samarinda. Jurnal Ilmu Komunikasi 1, 53-62 (2013).

37. Mustamin. Asupan energi dan aktivitas fisik dengan kejadian obesitas sentral pada ibu rumah tangga di kelurahan ujung pandang baru kecamatan tallo kota makassar. Media Gizi Pangan X, 6065 (2010).

38. Siswanto. Studi Diet Total: Survei Konsumsi Makanan Individu Indonesia 2014. Ministry of Health Republic of Indonesia (Badan Penelitian dan Pengembangan Kesehatan Kementerian Kesehatan RI, 2014). doi:978-602-109931-5

39. Widyaningrum, S. Hubungan antara Konsumsi Makanan dengan Kejadian Hipertensi pada Lansia. (Universitas Jember, 2012).
40. Burhan, F. Z., Sirajuddin, S. \& Indriasari, R. Pola Konsumsi Terhadap Kejadian Obesitas Sentral Pada Pegawai Pemerintahan Di Kantor Bupati Kabupaten Jeneponto. Kesehatan Masyarakat Universitas Hasanuddin 114 (2013).

41. Layman, D. K. Protein Quantity and Quality at Levels above the RDA Improves Adult Weight Loss. Journal of the American College of Nutrition 23, 631-636 (2004).

42. Hammadi, E. Al. Effects of Dietary Fiber Intake on Body Weight and Waist Circumference. Arab Journal of Nutrition and Exercise 1, 77-84 (2017).

43. Slavin, J. L. Dietary fiber and body weight. Nutrition (Burbank, Los Angeles County, Calif.) 21, 411-8 (2005).

44. Michi, J. Fibres against obesity. Wellness Foods \& Supplements (2015). 